\title{
DDK egg-foreign sperm incompatibility in mice is not between the pronuclei
}

\author{
J. R. Mann* \\ M.R.C. Mammalian Development Unit, Wolfson House (University College London), \\ 4 Stephenson Way, London NWI 2HE, U.K.
}

\begin{abstract}
Summary. A high rate of normal postimplantation development was achieved when the pronuclei of embryos from matings of DDK females with $(\mathrm{CBA} \times \mathrm{C} 57 \mathrm{BL} / 6 \mathrm{~J}) \mathrm{F}_{1}$ males were transplanted into enucleated embryos of non-DDK origin. This shows that the DDK egg cytoplasm, not the maternal pronucleus, is involved in the late preimplantation-lethal incompatibility.
\end{abstract}

\section{Introduction}

When female mice of the DDK strain are mated to male mice of other strains, litter size is substantially reduced. However, this does not occur in the reciprocal crosses. The effect is due to the death of many embryos between the morula and implantation stages, whereas postimplantation development in those embryos that survive this period is normal (Wakasugi, Tomita \& Kondo, 1967; Wakasugi \& Morita, 1977). Ovary transplantation experiments have shown that there is no contribution to the effect by the uterine environment of the mother (Wakasugi, 1973). The effect therefore involves the embryos alone, and is apparently due to an incompatibility between the DDK maternal pronucleus or egg cytoplasm, and the foreign spermatozoon.

In the study described here, these two possibilities have been distinguished by using nuclear transplantation at the one-cell stage.

\section{Materials and Methods}

DDK mice have been maintained as an inbred strain since they were brought to the Mammalian Development Unit by $\mathrm{N}$. Wakasugi in 1976. (CBA $\times$ C57BL/6) $\mathrm{F}_{1}$ (hereafter termed $\mathrm{CBF}_{1}$ ) mice were also bred in the Unit.

Pronuclei were transplanted according to the method of McGrath \& Solter (1983). Sendai virus is employed to fuse the pronuclei, surrounded by a small portion of egg cytoplasm and plasma membrane, into enucleated embryos.

DDK and $\mathrm{CBF}_{1}$ females were superovulated by intraperitoneal injection of 5 i.u. PMSG (Folligon; Intervet, Cambridge, U.K.) followed about $48 \mathrm{~h}$ later by 5 i.u. hCG (Chorulon; Intervet). They were mated to $\mathrm{CBF}_{1}$ males, and about $22 \mathrm{~h}$ after $\mathrm{hCG}$ injection, one-cell zygotes were isolated according to standard procedures (Biggers, Whitten \& Whittingham, 1971). $\mathrm{CBF}_{1}$ i $\times \mathrm{CBF}_{10} 0^{*}$ embryos were enucleated, and both pronuclei of $\mathrm{DDK}_{9} \times \mathrm{CBF}_{10} 0^{*}$ or $\mathrm{CBF}_{1}+\times \mathrm{CBF}_{10} \mathrm{e}^{-}$embryos were transplanted to them. They were cultured overnight to cleave to 2-cells, then replaced via the infundibulum into the ampullary region of the oviducts (Tarkowski, 1959) of $\mathrm{CBF}_{1}$ recipients on Day 0.5 of pseudopregnancy (day of vaginal plug after mating to

\footnotetext{
*Present address: Birth Defects Research Institute, Royal Children's Hospital, Flemington Rd, Parkville,
} Victoria 3052, Australia. 
vasectomized males of proven sterility). Embryos were handled and micromanipulated in Medium M2 (Fulton \& Whittingham, 1978) and cultured in Medium M16 (Whittingham, 1971) at $37^{\circ} \mathrm{C}$ in $5 \% \mathrm{CO}_{2}$ in air.

\section{Results}

\section{Reproductive performance in DDK mice}

Of 24 DDK females autopsied at 10.5 to 13.5 days of gestation (Day $0.5=$ day of vaginal plug) after mating to $\mathrm{CBF}_{1}$ males, 8 did not possess any implantation sites and the remaining 16 possessed a total of 127 obvious corpora lutea, 31 moles or resorptions and 25 normal embryos. Hence, the mean litter size would have been approximately 1.6 . This compares to 6.4 observed in our DDK breeding colony $\left(\mathrm{DDK}_{+} \times \mathrm{DDK}_{0}^{*}\right)$ over the time period when these data were collected, demonstrating an incompatibility between $\mathrm{DDK}$ eggs and $\mathrm{CBF}_{1}$ spermatozoa.

\section{Development of embryos after pronuclear transplantation}

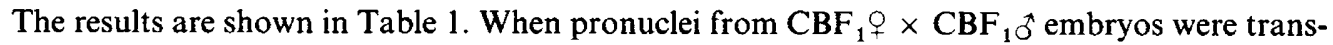
planted into enucleated $\mathrm{CBF}_{1}$ 우 $\times \mathrm{CBF}_{1} \mathrm{o}^{*}$ embryos, the proportion that developed after implanting was lower than in the controls. This suggests that the pronuclear transplantation procedure itself resulted in the failure of some embryos to develop beyond the implantation stage. In spite of this, a high rate of normal postimplantation development was achieved when pronuclei of the inviable

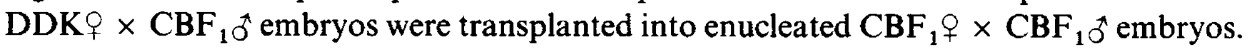

Table 1. Development of embryos after pronuclear transplantation

\begin{tabular}{|c|c|c|c|}
\hline \multirow[b]{2}{*}{$\begin{array}{l}\text { Pronuclear } \\
\text { donor embryos }\end{array}$} & \multicolumn{3}{|c|}{ Number of embryos } \\
\hline & Replaced* & Implanted & $\begin{array}{l}\text { Developed } \\
\text { normally after } \\
\text { implantation }\end{array}$ \\
\hline 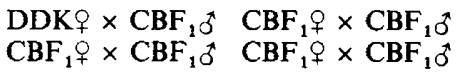 & $\begin{array}{l}16 \\
20\end{array}$ & $\begin{array}{c}\text { n.d. } \\
18\end{array}$ & $\begin{array}{l}12+ \\
11 \S\end{array}$ \\
\hline Control $\mathrm{CBF}_{1} \rho \times \mathrm{CBF}_{1} \sigma^{\uparrow}$ embryos $\dagger$ & 28 & 28 & $26 \prod_{1}$ \\
\hline \multicolumn{4}{|c|}{ 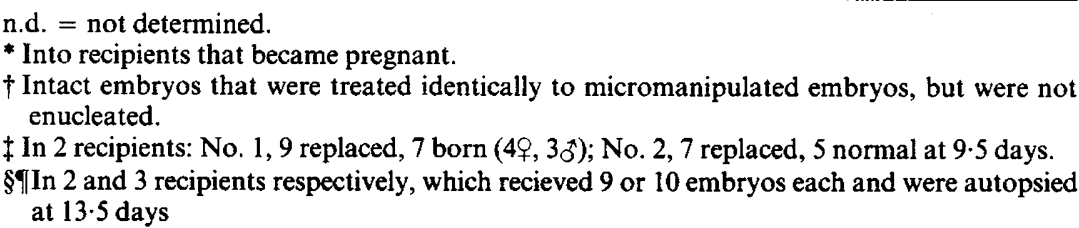 } \\
\hline
\end{tabular}

\section{Discussion}

These results show that the DDK maternal and $\mathrm{CBF}_{1}$ paternal pronuclei are fully compatible, since they can support a high rate of postimplantation development when combined with $\mathrm{CBF}_{1}$ cytoplasm. The inviability of $\mathrm{DDK}+\times \mathrm{CBF}_{1} 0^{*}$ embryos is therefore due to an incompatibility between components of the DDK egg cytoplasm or plasma membrane, and the $\mathrm{CBF}_{1}$ spermatozoon. 
This does not imply that the genetic control of the DDK incompatibility resides in the cytoplasm rather than in the nucleus, since the cytoplasm and plasma membrane are synthesized during oogenesis at least partly under the control of the oocyte nucleus. From studies involving intercrosses between DDK mice and other strains, Wakasugi (1974) has postulated that the incompatibility interaction takes place between the products of two closely linked genes, one synthesized during oogenesis, and the other expressed by the paternal genome. If this hypothesis is correct, the present results establish that, by the time of pronuclear transplantation, the maternal gene product must already have been exported out of the oocyte nucleus.

I thank Dr Anne McLaren for helpful advice and criticism of the text and Dr Mia Buehr for collecting data on the reproductive performance of DDK mice. I was supported by part of an Uncle Bob's Travelling Fellowship and the Birth Defects Research Institute, Royal Children's Hospital. Melbourne, Australia.

\section{References}

Biggers, J.D., Whitten, W.K. \& Whittingham, D.G. (1971) The culture of mouse ova in vitro. In Methods in Mammalian Embryology, pp. 86-116. Ed. J. C. Daniel Jr. W.H. Freeman and Co, San Francisco.

Fulton, B.P. \& Whittingham, D.G. (1978) Activation of mammalian oocytes by intracellular injection of calcium. Nature, Lond. 273, 149-151.

McGrath, J. \& Solter, D. (1983) Nuclear transplantation in the mouse embryo by microsurgery and cell fusion. Science N.Y. 220, 1300-1302.

Tarkowski, A.K. (1959) Experiments on the transplantation of ova in mice. Acta theriol. 2, 251-267.

Wakasugi, N. (1973) Studies on fertility of DDK mice: reciprocal crosses between DDK and $\mathrm{C} 57 \mathrm{BL} / 6 \mathrm{~J}$ strains and experimental transplantation of the ovary. J. Reprod. Fert. 33, 283-291.
Wakasugi, N. (1974) A genetically determined incompatibility system between spermatozoa and eggs leading to embryonic death in mice. J. Reprod. Fert. 41, 85-96.

Wakasugi, N. \& Morita, M. (1977) Studies on the development of $\mathrm{F}_{1}$ embryos from inter-strain crosses involving DDK mice. J. Embryol. exp. Morph. 38, 211-216.

Wakasugi, N., Tomita, T. \& Kondo, K. (1967) Differences of fertility in reciprocal crosses between inbred strains of mice: DDK, KK and NC. J. Reprod. Fert. 13, 41-50.

Whittingham, D.G. (1971) Culture of mouse ova. $J$. Reprod. Fert. Suppl. 14, 7-21.

Received 3 September 1985 